\title{
Primary Amyloid Goitre
}

\author{
C. Aparna, I. V. Renuka, G. Saila Bala, M. Vijayasri \\ Department of Pathology, Guntur Medical College, Guntur, India \\ Email: repriya56@gmail.com
}

Received July 3, 2013; revised August 2, 2013; accepted August 25, 2013

Copyright (C) 2014 C. Aparna et al. This is an open access article distributed under the Creative Commons Attribution License, which permits unrestricted use, distribution, and reproduction in any medium, provided the original work is properly cited. In accordance of the Creative Commons Attribution License all Copyrights (C) 2014 are reserved for SCIRP and the owner of the intellectual property C. Aparna et al. All Copyright (C) 2014 are guarded by law and by SCIRP as a guardian.

\section{ABSTRACT}

Goitre is defined as the presence of amyloid within the thyroid gland in such quantities as to produce a clinically apparent enlargement. We report a case on a fifty-two-year-old female patient who presented with a rapidly growing thyroid swelling. Thyroid function tests were normal. This case was diagnosed as amyloid goitre and was discussed in detail along with review of literature.

\section{KEYWORDS}

\section{Amyloid; Goitre}

\section{Introduction}

Some degree of microscopic amyloid is seen in generalized amyloidosis. Minor amyloid infiltration of thyroid gland is seen in $50 \%$ - $80 \%$ of cases of generalized amyloidosis, and the induction of a goitre by amyloid invasion is rare [1,2]. Though there is a rapid enlargement of thyroid gland, thyroid function tests are normal.

\section{Case Summary}

A fifty-two-year-old female came to the otolaryngology department with the complaint of a rapidly growing thyroid swelling. On clinical examination there was enlargement of one lobe of thyroid. No toxic symptoms were seen. Thyroid profile was normal. Fine needle aspiration was done, which showed macrophages and colloid, and was reported as nodular goiter. Subtotal thyroidectomy was done. Grossly we received a hemithyroidectomy specimen measuring $6 \times 5 \times 3 \mathrm{cms}$; weighing 56 Gms. External surface was smooth. Cut section was diffuse grey brown. Eight sections were submitted. Histopathology showed few atrophied thyroid follicles, some follicles were filled with colloid and thyroid parenchyma was virtually replaced by a pink, homogeneous substance, along with extensive adipose tissue (Figure 1, 2). We made a differential diagnosis of medullary carcinoma of thyroid and amyloid goitre. Congo red stain was positive for the pink homogeneous substance and it showed an apple green birefringence under polarized light (Figure 3). Immunohistochemistry (IHC) for Calcitonin and amyloid associated Protein was negative. Once the extracellular substance was confirmed as amyloid, we have done a complete skeletal survey, serum electrophoresis and urine bence jones proteins, all the tests were negative. Ultrasound abdomen was done to rule out hepatosplenomegaly. There was no history of any chronic

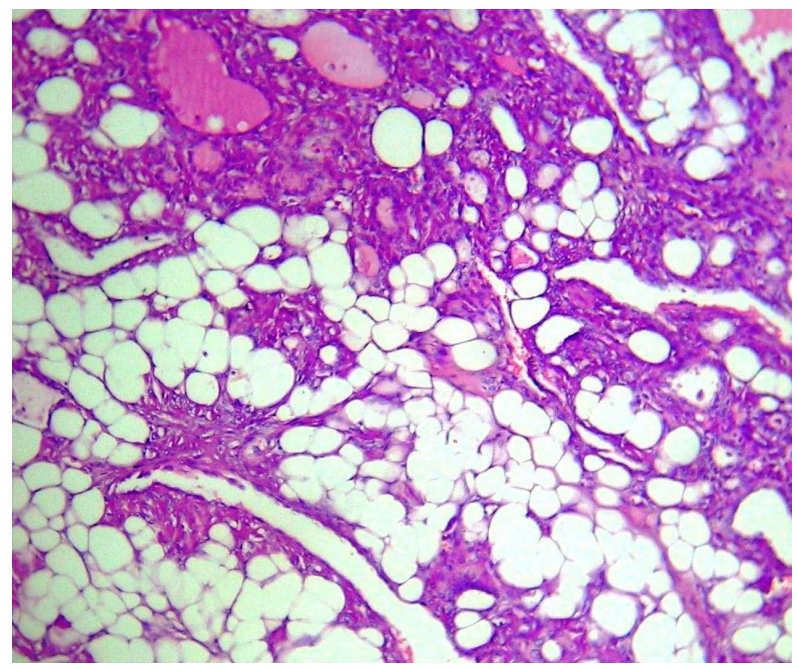

Figure 1. Gross photograph of the lobectomy specimen. 


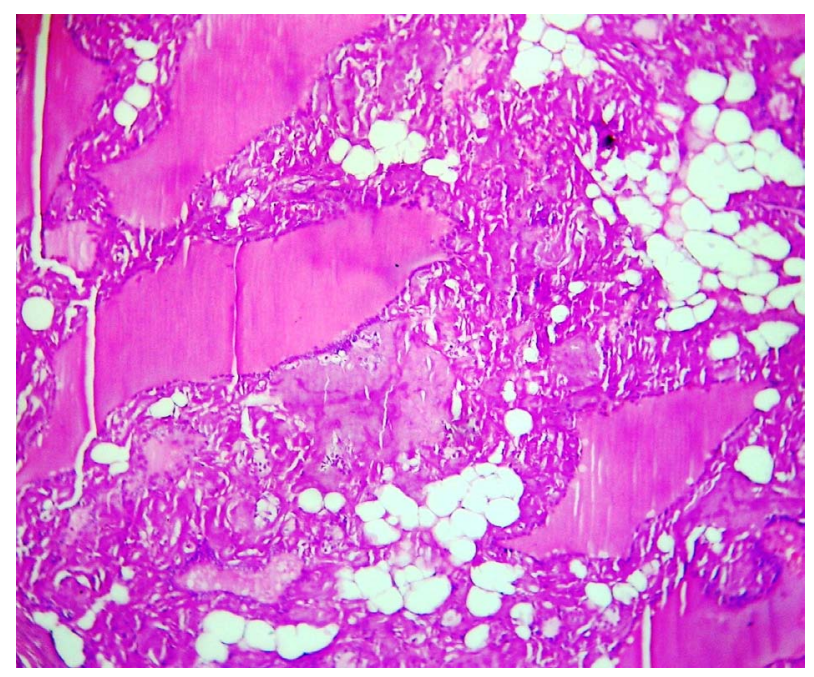

Figure 2. H\&E x400; Thyroid follicle filled with colloid and extensive adipose tissue.

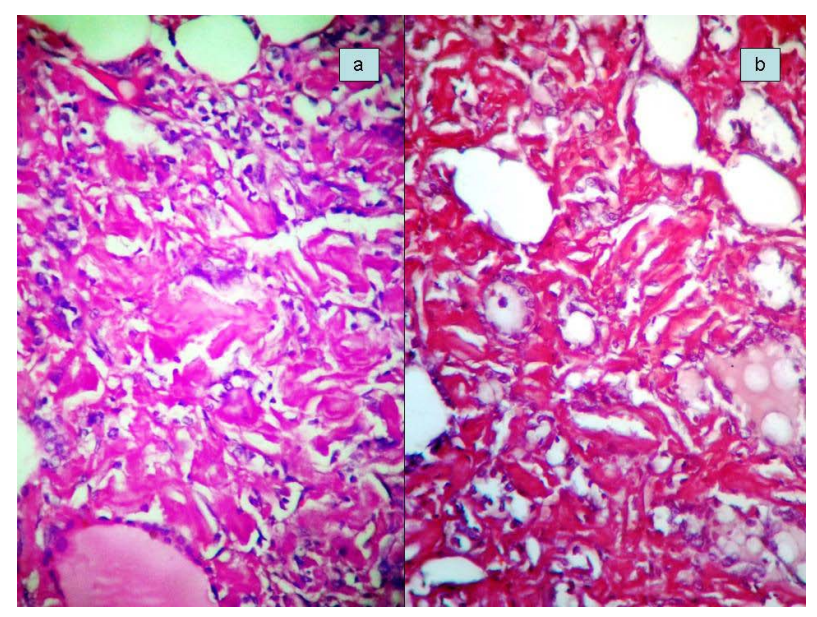

Figure 3. H\&E x400; extensive amyloid deposition, with congored stain.

illness like bronchiectasis, tuberculosis, chronic renal failure or rheumatoid arthritis. Trans abdominal fat biopsy was done and stained for congo red to rule out systemic amyloidosis. Post operatively patient was doing well after one and half years and did not show any features of systemic amyloidosis.

\section{Discussion}

Presence of minor amyloid deposits in thyroid was described in 1855 by Von Rokitansky and clinically detectable goitre due to Amyloid was recorded by Beckmann in 1858. In 1904 Eiselberg coined the phase "Amyloid goitre" [3-5]. Amyloid goitre may be associated with either primary or secondary amyloidosis [5]. Secondary Amyloidosis is seen in any chronic disease like tuberculosis, bronchiectasis, chronic renal failure, rheumatoid arthritis, familial Mediterranean fever, etc.
Amyloid goitre is seen in $0.04 \%$ of primary systemic amyloidosis, but primary localized Amyloid goitre is very rare, when it occurs, the enlargement of the gland is rapid [3]. Clinical history ranges from four months to three years. Thyroid enlargement may be unilateral or bilateral. The gland is firm to hard in consistency, though in few cases it is soft. Cut surface varies in color. Histologically there will be extensive intercellular amyloid deposition, thyroid follicles lined by atrophic epithelium, filled with colloid, fatty metaplasia and sometimes squamous metaplasia may also be seen. It may be associated with foreign body giant cell reaction. Most of the patients are in euthyroid state, but in a few cases either hypo or hyperthyroid state was seen [3].

There is no medical treatment available for amyloid goitre. Surgical treatment is aimed at relieving pressure symptoms. Secondary amyloidosis tends to have a better prognosis than that of primary. Regarding the pathogenesis amyloid may be immunocyte derived but the reason for either fatty metaplasia or squamous metaplasia was obscure. In the present case, patient presented with rapidly enlarging thyroid gland, histopathology showed atrophied follicles, filled with colloid, extensive amyloid deposition and fatty metaplasia. There was no background "C" cell hyperplasia; Authors like Rijaswik have done potassium permanganate incubation to differentiate primary amyloidosis from secondary amyloidosis [6]. But we have done IHC for Calcitonin and Amyloid Associated Protein which were negative. Hence medullary carcinoma of thyroid and secondary amyloidosis was ruled out. We have excluded multiple myeloma also by serum electrophoresis and skeletal survey. Primary systemic amyloidosis was also ruled out by transabdominal fat biopsy and ultrasound abdomen. We have used the classification given by Cathcart et al. (Table 1) and concluded this case as primary localized Amyloidosis, Class 1c. In the literature Yatin sethi and K. Pai reported a similar case but it was in a male patient $[3,7]$.

\section{Conclusion}

This case is presented because of its clinical significance. It has to be differentiated from medullary carcinoma of

Table 1. Classification of amyloidosis.

\begin{tabular}{ll}
\hline Primary amyloidosis & $\begin{array}{l}\text { a) systemic non familial } \\
\text { b) familial } \\
\text { c) localized }\end{array}$ \\
Lymphoproliferative & $\begin{array}{l}\text { a) multiple myeloma } \\
\text { b) plasmacytoma }\end{array}$ \\
c) other lymphoproliferative disorders & a) chronic infections \\
Secondary amyloidosis & $\begin{array}{l}\text { b) chronic inflammations } \\
\text { c) non lymphoproliferative malignancies }\end{array}$ \\
\hline
\end{tabular}


thyroid as treatment and prognosis are completely different.

\section{REFERENCES}

[1] P. Duhra and J. Cassar, "Thyroid Function Tests in Amyloid Goiter,” Postgraduate Medical Journal, Vol. 66, No. 774, 1990, pp. 304-306.

http://dx.doi.org/10.1136/pgmj.66.774.304

[2] P. D. James, “Amyloid Goiter,” Journal of Clinical Pathology, Vol. 25, No. 8, 1972, pp. 683-688.

[3] Y. Sethi, A. Gulati, I. Singh, S. Rao and N. Singh, "Amyloid Goiter: A Case of Primary Thyroid Amyloid Disease," The Laryngoscope, Vol. 121, No. 5, 2011, pp. 961-964. http://dx.doi.org/10.1002/lary.21459

[4] L. Yildiz, M. Kefeli, B. Kose and S. Baris, "Amyloid
Goiter: Two Cases and a Review of the Literature,” Annals of Saudi Medicine, Vol. 29, No. 2, 2009, pp. 138-141. http://dx.doi.org/10.4103/0256-4947.51808

[5] R. Khuller, A. Sharma, A. Goel, N. Bagchi, V. Soni, M. Baijal and P. K. Chowbey, "Amyloid goiter: A Rare Case Report,” Indian Journal of Surgery, Vol. 68, No. 2, 2006, pp. 104-105.

[6] M. H. Van Rijswik and C. W. Van Heusden, "The Potassium Permanganate Method, A Reliable Method for Differentiating Amyloid AA from Other Forms of Amyloid in Routine Laboratory Practice," American Journal of Pathology, Vol. 97, No. 1, 1979, pp. 43-58.

[7] K. Pai and L. Ramachandra, M. S. Susmitha and B. P. Suresh, "Amyloid Goiter: A Case of Primary Thyroid Amyloid Disease,” The Internet Journal of Surgery, Vol. 22, No. 2, 2010, pp. 1-4. 